\title{
地震時の木造建築物倒壊に伴う死者数推定に向けた棟死亡率関数の提案 SEISMIC DEATH RISK FUNCTION FOR CASUALTIES PER HOUSE
}

\author{
田畑直樹*, 岡田成幸** \\ Naoki TABATA and Shigeyuki OKADA
}

\begin{abstract}
In Japan, almost all the earthquake casualty occurs inside wooden houses damaged. For decreasing the casualties due to damaged wooden houses, the precise estimation method is indispensable. Combining the data on damaged buildings surveyed in the field of earthquake engineering and the data on death bodies inspected in the field of disaster medicine in the 1995 Hyogo-ken Nanbu earthquake, we found that earthquake casualties have close relation not only to the damage degree of their houses but also to the building damage ratio around the dwelling area. We proposed the death rate function with the parameters of them in order to precisely estimate casualties per house. Proposed functions are also applicable for the effective seismic reinforcement plan for the house to decrease the casualties in the municipality or governmental unit.
\end{abstract}

\author{
Keywords: 1995Hyogo-ken Nanbu Earthquake, Damage Index, Seismic Death Rate Function, \\ Lower Wooden House, Human Casualty, Inhabitant's Existence Ratio \\ 1995年兵庫県南部地震，損傷度，棟死亡率関数，木造低層建物，人的被害，在宅率
}

\section{1. 既往推定式の問題点と本研究の目的}

1995年の兵庫県南部地震は、我が国で初めて震度 7 を記録した都市 直下地震であり、神戸市を中心として数多くの建築物とりわけ木造住 家が多数損壊し、深刻な人命損失をもたらした。震災後、既存不適格 建築物の問題が広く認知され、旧建設省住宅局監修の耐震精密診断1) の受診数が年々増加傾向にあること、また、法整備として耐震改修促 進法が施行されるなど住家の安全性向上が急がれているが、行政を主 体とする地震防災対策の基本となる、住家の倒壊に伴う死者数の予測 に関する研究は、構造物の被害評価のそれと比較すると甚だ少なく、 旧来からの推定式を末だ援用している状況にある。

地震時の木造住家破壊に伴う死者数推定の端緒は以下の 1950 年代 のKawasumi ${ }^{2}$ に遡る。ここにDは死者数、Hは木造全壊数である。

$$
D=0.01 \times H^{1.3}
$$

1970年代には、東京都 ${ }^{3}$ )が被害想定のために、木造全壊数 $H$ (但し、 全壊数 $+0.2 \times$ 半壊数として計算) に加吕家屋焼失数 $F$ を説明要因とし た以下の関数を用いている。

$$
\log _{10} D=0.95987 \times \log _{10}(H+F)-1.02912
$$

1980年代には、太田・他 ${ }^{4}$ が建物被害・火災数・地震規模等を多要 因とした重回帰モデルに言及している。 1990年代には、Coburn et al ${ }^{5}$ が゙組積造及び鉄筋コンクリート造建物 被害から、死者数を崩壊建物数とそれに伴う閉じ込め及び建物内人口
などを要因としたモデル化を試みている。最近では内閣府的が地方公 共団体における地震被害想定を支援する目的で、以下の評価式（ $D r$ は死者率、Hrは全壊率)を使ってWeb上で支援ツールを公開している。 $\mathrm{Dr}=0.0359 \times \mathrm{Hr}$

その他、福島・他》は兵庫県南部地震被害記録を利用し探求的デー 夕解析の手法を用いて木造住家の全壊率と死亡率の関保を議論して いる。また、近年懸念される東海地震被害想定においても、過去に発 生した被害地震における全壊数と死亡者数を 1 次式で回帰した以下 の関数（Pは屋内人口）が用いられており 、現在多くの自治体で行 われる地震時人的被害予測も類似の関数を採用している。

$$
D=0.0629 \times H r / 100 \times P
$$

既往式は基本的に地域に発生する人的被害の概数をマクロ的に推 定するためのものであり、被害建物数からの1次式回帰のため個々の 建物の損傷程度と死亡危険性との関係が不明であり、推定精度が低い。 特に、大規模被害地震においては死者数は過小評価され、小規模被害 地震においては過大評価の傾向が目立つ。さらに問題なのは、建物耐 震化等の減災対策による人的被害軽減化効果が評価できないことで ある。加えて近年、建物被害評価の分野において、減災に向けたミク 口対策の必要性から、個別建物の損傷評価関数が提案9されてきてい る。人的被害評価においても地域主体から個別世帯評価へと推定精度 向上そしてミクロ対策への利用可能性を狙った新しい評価式が切望
Graduate Student, Grad. School of Engineering, Hokkaido University, M. Eng. Tokio Marine \& Nichido Risk Consulting Co., Ltd.

Prof., Grad. School of Engineering, Nagoya Institute of Technology, Dr. Eng.
*北海道大学大学院工学研究科 修士(工学)
(現 東京海上日動リスクコンサルティング(侏)

** 名古屋工業大学大学院工学研究科 教授. 工博 
される。さらに、式の利便性を高めるには、説明㚆数として入手容易 な資料によっていることが条件として加わる。

本研究は以上の目的意識の基、既往式よりも推定精度が高く、特に 大規模地震に対する過小評価・小規模地震に対する過大評価の原因に 踏み込みつつ、個別の建物損傷から棟別に死者推定が可能なミクロレ ベルの棟死亡率関数を提案する。提案式の防炎工学的意義は、一つに は、防災行政にとって対策の基本となる地域内死者数がより高精度に 推定可能になるということ。例えば、本提案式をシナリオ地震に適用 し甚大な死者数が発生する地域を推定することで、特定地域への耐震 補強促進を進める意思決定の材料と成り得る。また個別の損傷程度に 着目するので、個々の建物内での死亡リスクを評価することが可能に なり、例えば死亡危険性を目標值まで下げるのに必要な建物損傷の許 容値を測り知ることが可能となったり、地域をより細分化しても推定 精度が低下しないなど、よりきめ細かな地域防災対策へ貢献できると 考える。

\section{2. 研究方法}

建物の損傷状態とその建物内での死亡率との関係を求めるのが本 研究の主題である。研究の流れは大まかに、建物倒壊に伴う死者を多 く発生した1995年兵庫県南部地震の建物被害・人的被害を基本資料之 し関係を構築する。そして提案式の有用性を検封するため既往式との 推定精度比較を行う。

本研究で必要どした基本資料は、建物の属性（木造／非木造、階数、 独立／集合、建築年、被害状態等）及び住人属性（建物内居住者数、 死亡者数、死亡状況等) である。また、地域の地震動の大きさの違い も考慮する必要がある。建物被害については、航空写真を立体視（屋 根と壁面の破壊状態を同時考慮）する写真判読法により行った。比較 的短時間で被害判定が可能でかつ精度が高い理由からである。小川・

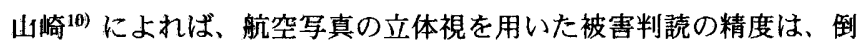
壊LEVELで特に高く、後段D5・D6 LEVELでは凡そ90\%の割合で地上 調查結果と一致する。兵庫県南部地震の被害については、震災復興ま ちづくり特別委員会 (以下、震特委員会) の建物被害判定 ${ }^{11}$ (全壊ま たは大破、中程度の損傷、軽微な損傷、無被害の4段階区分）が広く 用いられてはいるが、本論では、より詳細な建物の損傷程度之人的被

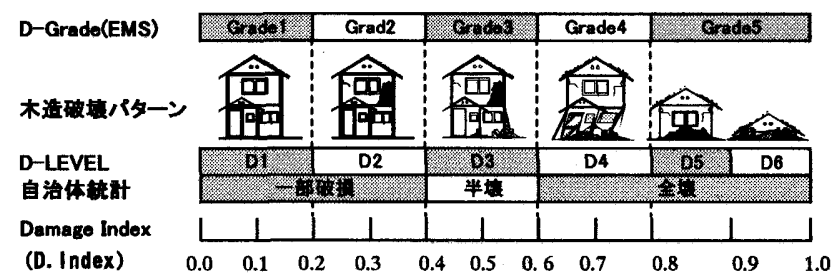

図1 各種の被害尺度の関係 ${ }^{9)}$

表1 本論で用いる被害尺度

\begin{tabular}{|c|c|}
\hline & 被害状況 \\
\hline \multirow{9}{*}{ 被災度判定定轿 } & D6 (全褧) : 宾全崩垗 \\
\hline & D5(全堙):1.2階どちらかの層破壊 \\
\hline & D4(全壊): 柱·梁の破壊による内部空間の欠損 \\
\hline & 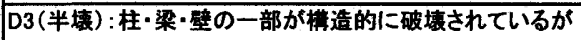 \\
\hline & 内部空間を欠攅するような被害は生じていない \\
\hline & D2(一部破損):屋根瓦·壁面のモルタル等の大幅な剥落 \\
\hline & 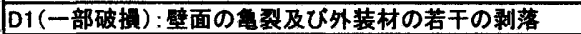 \\
\hline & DO: 無被富 \\
\hline & 火災 \\
\hline
\end{tabular}

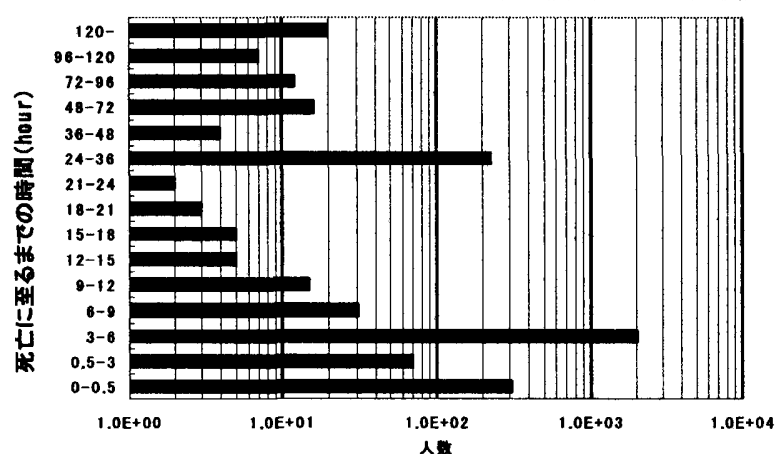

図3 死亡に至るまでの時間の内訳 (火災による死亡を除く)

表2 対象とした木造低層建物被害数の菓計

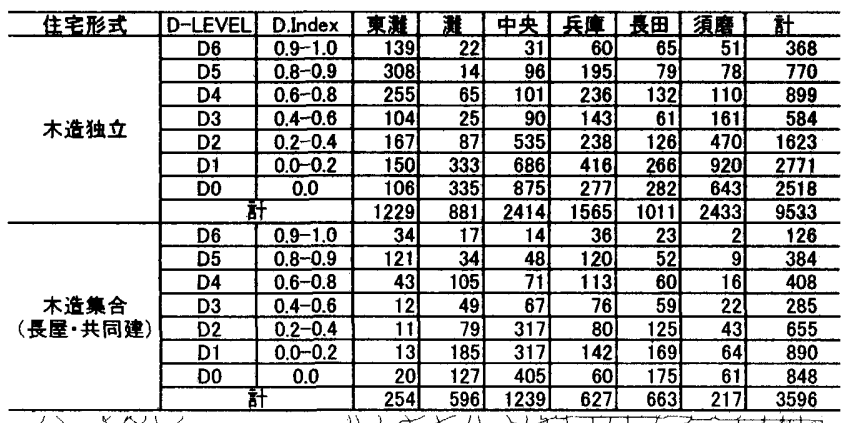

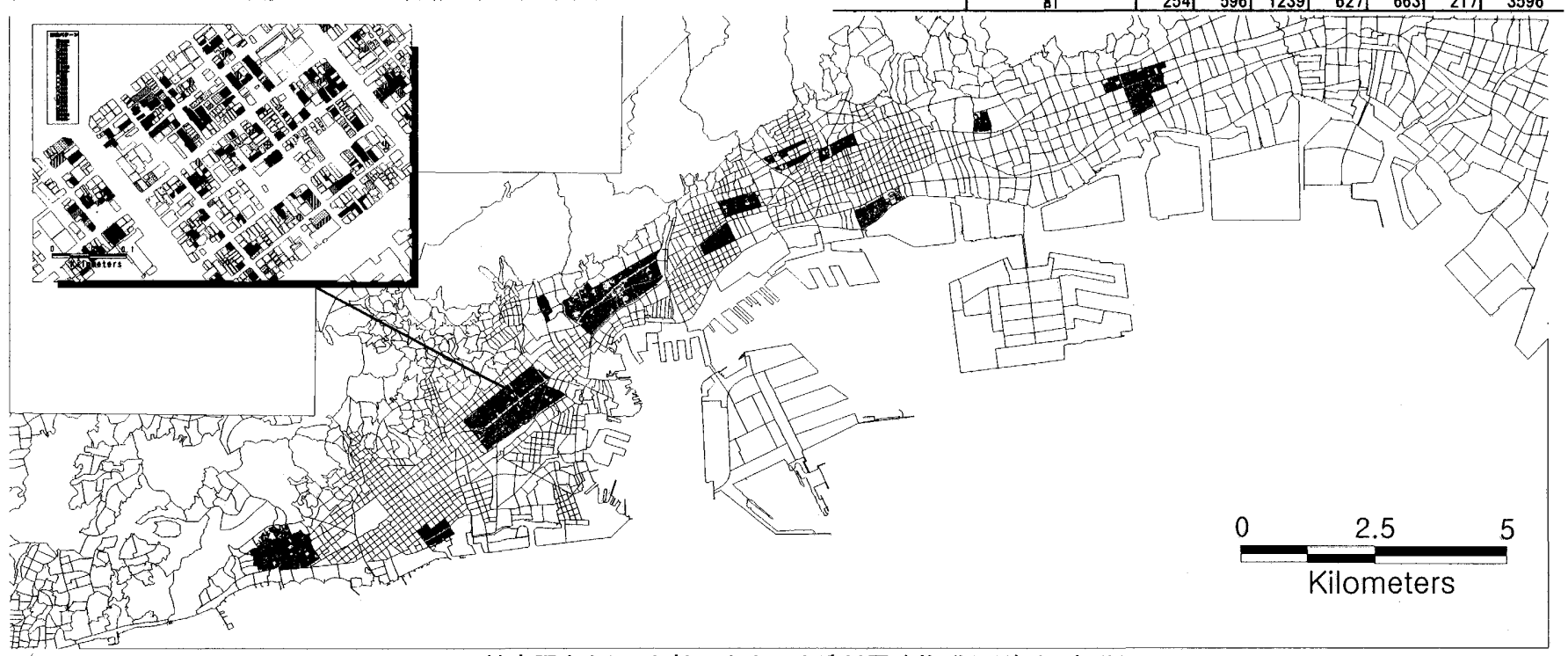

図2 被害調查を行った神戸市内の木造低層建物群(黒塗りの部分) 


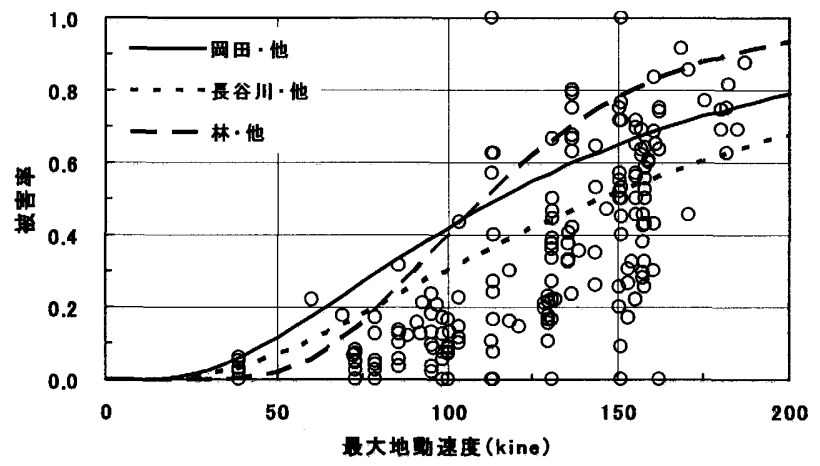

(1)D3以上被害率

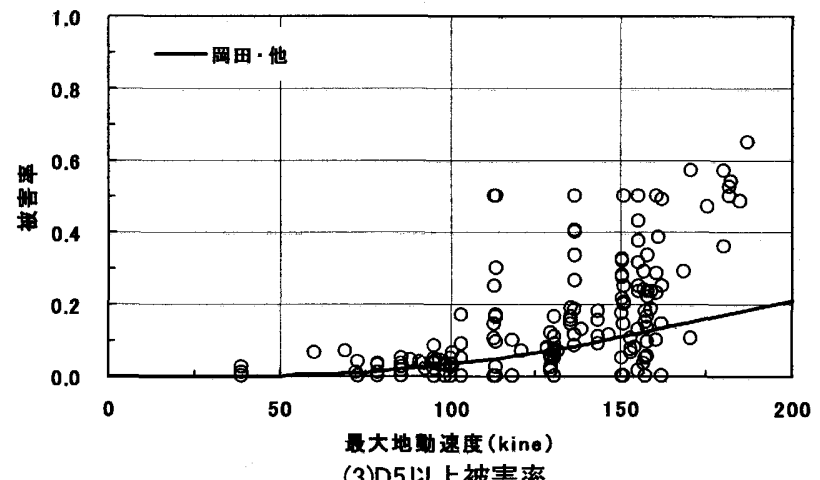

(3)D5以上被害率

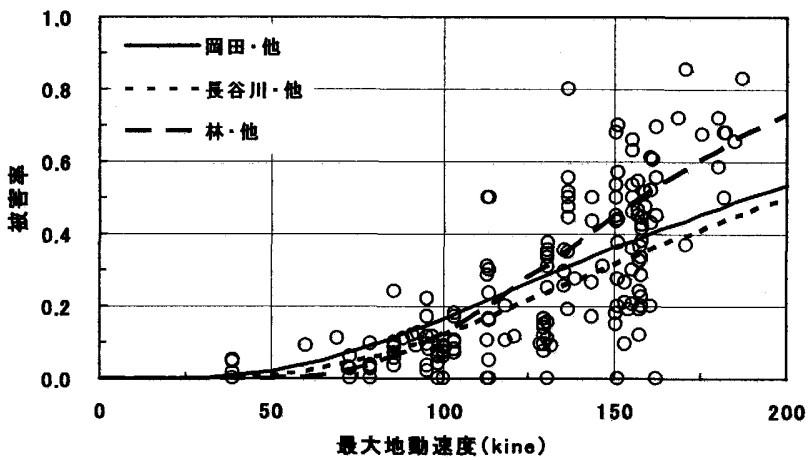

(2)D4以上被害率

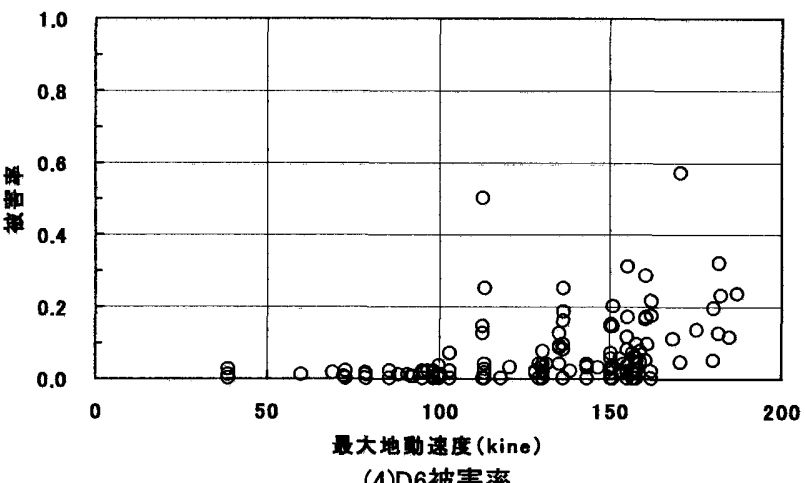

(4)D6被害率

図4 推定最大地動速度 (林·他 $\left.{ }^{14)}{ }^{15}\right)$ と木造低層建物被害率

害の関係を明らかにする目的と、被害尺度自体の曖昧さを取り除くた めに、被害判定精度が調查主体に殁ど依存せず、外観目視（本研究で は航空写真の立体視）で容易に判定可能でかつ、損傷程度が細かく区 分された岡田・高井 ${ }^{12}$ ) の破壊パターン（図1）を用い、7段階のDamage LEVEL（以降、D-LEVELと略称（表 1））で判定した。判定は総計5 名で行ったが、個人の被害判定基準の癖を補正するために予め数十件 の同一建物でキャリブレーションを行い、判定基準の相互確認を行つ ている。航空写真は火災煙の掛かっていない鮮明なもので、かつ被災 直後に撮影されたものの中から建物倒壊が主被害の地域で一般木造 の多い地域のものを選択した（撮影縮尺1:4000、拡大時1:500）。図2 に被害判読を行った地域を示す。凡そ“震災の帯”に位置する。また、 複数の区域に跨って地区を選定することで、人口密度・被害率の影響 が考慮可能となる。対象地域内に立地している全建物の内、非木造建 物と工場及び業務建物を除き被害判読した建物総計は13,129棟であ る。建物に関するその他の情報として、震特委員会がまとめた建物属 性（構造、住宅形式、用途）を用いた。

人的被害データとして用いたのは、神戸市内の監察医が記録した死 体検案書を西村 ${ }^{13)}$ が編集したものである。総デー夕数は5,411名、そ のうち判読建物内死亡者数は507名（東灘区207名、灘区39名、中央区 47 名、兵庫区128名、長田区42名、須磨区44名）である。本論は建物 の損傷による死者発生に限定して考えているので直接死因が建物損 傷と関係の薄いもの（焼死、ショック死等）については解析対象から 除外した。図3は、上記資料より死亡までの時間内訳を示したもので ある。多くが 6 時間以内に死亡しており、要救助時間を考えると建物 倒壊による重傷者の救助は極めて厳しいことが分かる。耐震補強等の 事前対策が人的被害軽減の基本であることが改めて知らされる。
以上の基本資料に、地域の地震動分布として林・他 $\left.{ }^{14,15}\right)$ が町丁目ご とに推定した最大地動速度分布を加え、地理情報システム（GIS）を 用いてデー夕統合を行った。統合にあたり、国交省建築研究所が作成 したGIS建物ポリゴン11）(図2）を利用した。

\section{3. 木造低層建物損傷度と死亡危険度の関係}

\section{1 木造低層建物被害の概要}

被害判定を行った木造低層建物の内、破壊パターンが判明したもの についてD-LEVEL（図1,表1参照）で集計し表 2 に示す。建物数は中 央区が最も多い。全壊数・全壊率（D4 LEVEL以上に相当、図1参照） ともに最も高かったのは東灘区であり、同区で人的被害が多く発生し たことに対応している。建物被害を町丁目ごとにD-LEVELで集計し 被害率に換算し、推定最大地動速度との関係を既往の被害率関数 12,15,16) と共に図4に示す。被害率関数は多くの研究者により種々提案さ れているが、多くは全壊・半壊・一部破損・無被害の4区分である。 しかし後段（図6）で示すとおり、死者発生は建物の全壊の尺度をよ り高分解することにより説明される。現状でそれに対応している関数 は筆者らによるもののみである注)。同図より、既往の被害率関数之 今回の判読データとは概ね一致しており、今回判読対象とした建物の 被害発生状況は一般性が保証されていると言えよう。ただし、D3（半 壊）は、判読被害の方が被害率関数に比べてやや小さい傾向にある。 航空写真を用いた被害判定では建物傾斜を伴わないD3 LEVEL以下 の被害を正確に判読することが難しく実態よりも被害を過小評価し ている可能性はあるが、後述（図6）のように、人的被害は大多数が D4 LEVEL以上とりわけD5・D6 LEVELで発生するので、以降の解析 への影響はない。D5 LEVELでは筆者らによる関数しか提案されたも 
のはないが、判読被害の方が被害率関数に比べてかなり高いように見 える。しかしこれは、筆者らによる関数がD5 LEVELとD6 LEVELの 区別は提案当時していなかったためでD5以上LEVEL関数と呼ぶべき である。同図によればほぼ本論D6 LEVELの判読被害率の上限を与え ているのが分かる。

\section{2 木造低層建物内の棟人口の推定}

木造低層建物の損傷度と死亡危険度の関係を明らかにするために は、地震発生時の 1 棟ごとの在宅人口を正確に知る必要がある。しか しそのようなデータは入手困難なため、各種統計資料から推定するこ ととする。木造低層建物には、一般に、住宅形式として一戸建・長屋 建・共同建があり、1 棟当たりの世带数がそれぞれ異なる。また、核 家族化が進んだ大都市・市区と郡・町村部では世帯構成人員も大きく 異なることが予想される。本研究では、総務省住宅統計 ${ }^{17)}$ (平成5年 版都道府県編)の市区統計表を用い、区別の棟当たり居住人口を以下 に推定する。

（1）木造独立（一戸建）住宅

住宅土地統計の中から、持ち家（ほほ一戸建てに等しい）の 1 住宅 当りの居住室数 $R n_{m}$ 及び持ち家 1 室当りの人員 $P n_{m}$ に着目し、木造独 立（一戸建）住宅の世帯人員 $F w$ を以下で表されるとする。

$$
F w=R n_{m} \cdot P n_{m}
$$

一般的に、一戸建住宅 1 棟当りの世帯数は1.0に近いと考えられる ので、Fwは木造独立住宅の棟当たり居住人口に等しいと見做せる。

（2）木造集合（長屋建・共同建）住宅

1 棟の中に複数の世帯が存在する住宅形式であるので、1世帯人員 に 1 棟当りの世帯数を乗じることで近似する。平成 5 年住宅統計 ${ }^{18}$ (全 国編）より、木造集合（長屋建・共同建）住宅における両形式（長屋 建 : 2.76 ,共同建 : 5.63）の 1 棟当り住宅数の平均値（4.2）を用いる。 結局、木造集合（長屋建・共同建）住宅の 1 棟人口は、次のように 表せる。

表3 推定した木造独立及び集合住宅の棟人口

\begin{tabular}{|c|c|c|c|c|c|c|}
\hline 住宅形式 & 東灘 & 灘 & 中央 & 兵庫 & 長田 & 須磨 \\
\hline 木造独立 $F w$ & 3.03 & 2.92 & 2.79 & 2.83 & 2.9 & 3.31 \\
\hline 木造集合 $G w$ & 12.7 & 12.2 & 11.7 & 11.9 & 12.2 & 13.9 \\
\hline
\end{tabular}

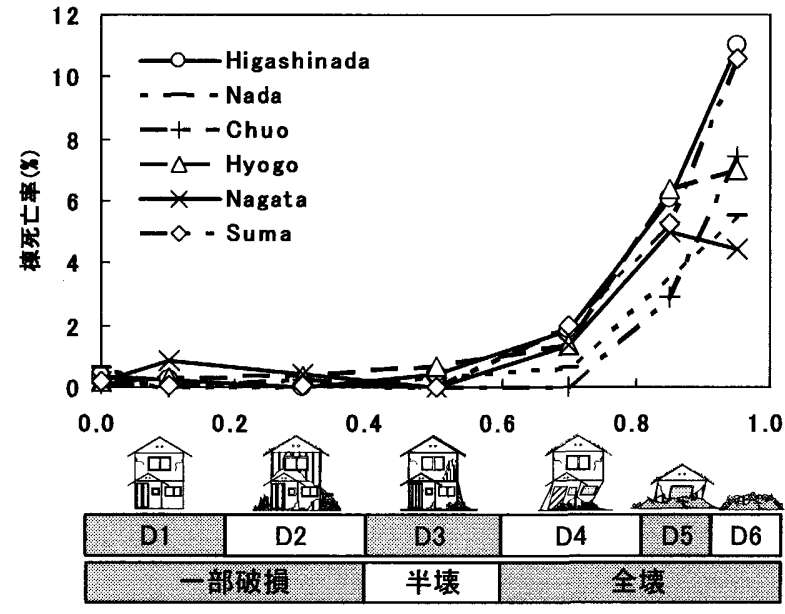

（1）木造独立 (一戸建)
（2）木造集合 (長屋建·共同建)
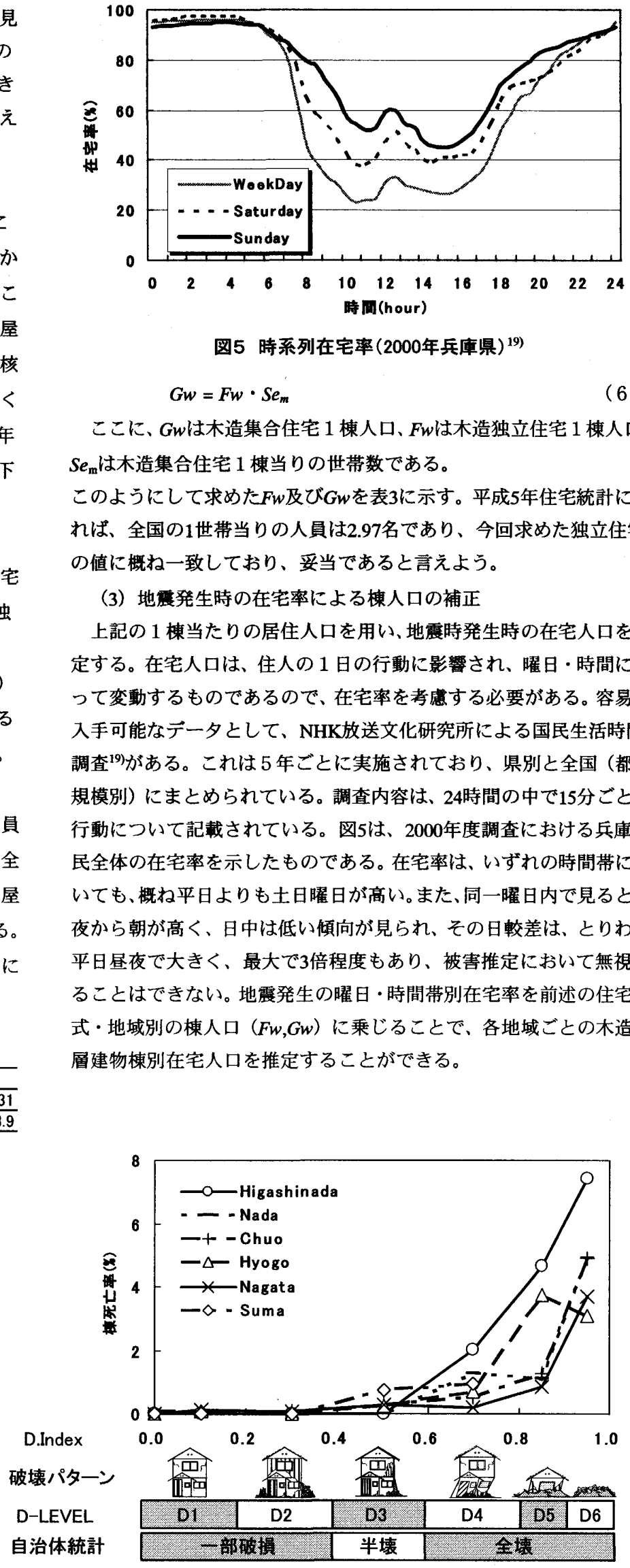

図5 時系列在宅率(2000年兵庫県 $)^{19)}$

$G w=F w \cdot S e_{m}$

ここに、Gwは木造集合住宅 1 棟人口、Fwは木造独立住宅 1 棟人口、 $S e_{\mathrm{m}}$ は木造集合住宅 1 棟当りの世帯数である。

このようにして求めた $F w$ 及び $G w$ を表3に示す。平成5年住宅統計によ れば、全国の1世帯当りの人員は2.97名であり、今回求めた独立住宅 の值に概ね一致しており、妥当であると言えよう。

（3）地震発生時の在宅率による棟人口の補正

上記の 1 棟当たりの居住人口を用い、地震時発生時の在宅人口を推 定する。在宅人口は、住人の 1 日の行動に影響され、曜日・時間によ って変動するものであるので、在宅率を考虑する必要がある。容易に 入手可能なデータとして、NHK放送文化研究所による国民生活時間 調査 ${ }^{19}$ がある。これは 5 年ごとに実施されており、県別と全国（都市 規模別）にまとめられている。調査内容は、24時間の中で15分ごとの 行動について記載されている。図5は、2000年度調查における兵庫県 民全体の在宅率を示したものである。在宅率は、いずれの時間帯にお いても、概ね平日よりも土日曜日が高い。また、同一矅日内で見ると、 夜から朝が高く、日中は低い傾向が見られ、その日較差は、とりわけ 平日昼夜で大きく、最大で3倍程度もあり、被害推定において無視す ることはできない。地震発生の曜日・時間帯別在宅率を前述の住宅形 式・地域別の棟人口 $(F w, G w)$ に乗じることで、各地域ごとの木造低 層建物棟別在宅人口を推定することができる。

図6 木造低層建物損傷度と棟死亡率 $(\%)$ 

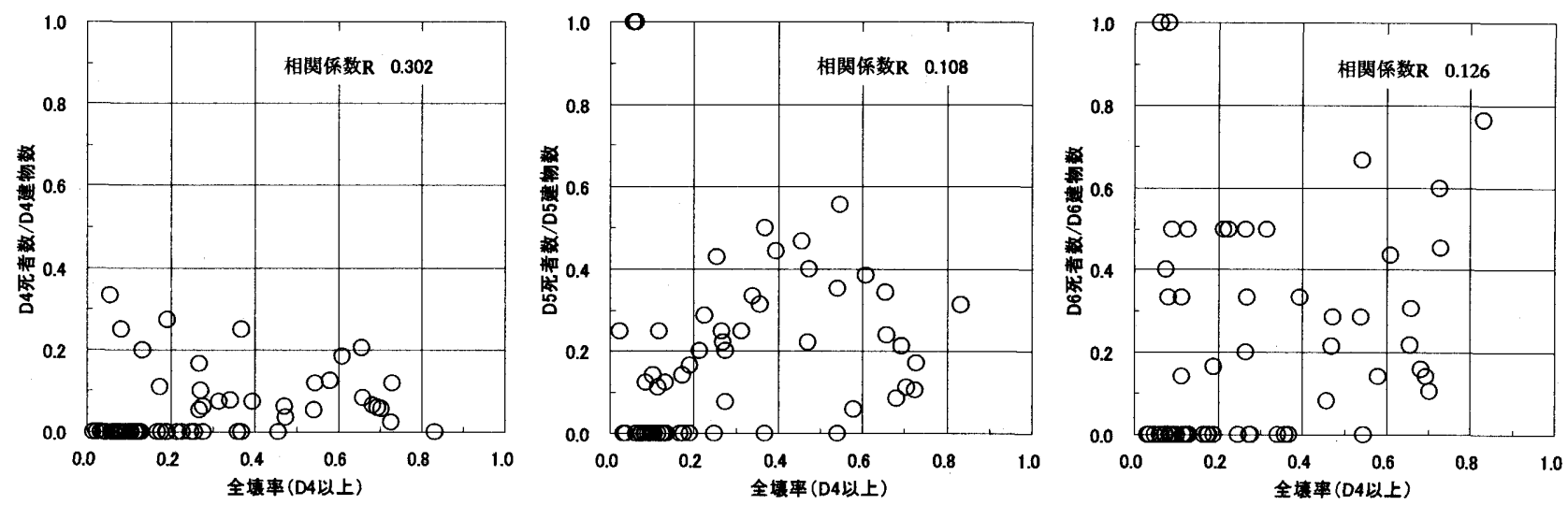

図7 周辺全媴率と損傷度別棟死亡数の関保(町丁目集計)

\section{3 木造低層建物の撌傷度別死亡率}

前節で求めた木造低層建物被害デー夕及び建物棟別推定在宅人口 を用いて、木造低層建物 1 棟に対応する死亡率を被害との関保につい て議論する。建物 1 棟ごとの被害（損賃度）は死者発生との関係を議 論する際、詳細尺度で記述されるのが望ましく、また、次節の関数化 においては連続量として报えるのが望ましい。筆者らはそのための被 害尺度として既往研究》においてDamage Index（以降、D.Index と略称） を定義しており（定義域 $[0,1.0] ，($ 図1））、地震動強さと建物 1 棟 ごとの被害との関係を損傷度関数として提案している。本研究でもこ れに準拠し、 1 棟ごとの在宅居住者人口に対する木造低層建物死亡率 を棟死亡率と呼び、建物損偈度（D.Index）をパラメー夕に以下に定 義する（式(7) (8)）。

$$
\operatorname{Dr}(x)=\frac{\sum_{i=1}^{N_{m}} D n(x)_{i}}{\sum_{i=1}^{N_{m}} P n(x)_{i}} \cdot 100
$$

$P n(x)=P w \cdot E r$

ここに、Dr(x) はD.Index別棟死亡率（\%）、 $N_{m}$ はD.Index別の棟数、 $x$ はD.Index、 $D n(x)_{i}$ はD.Index別墦目の棟死者数、Pn(x) $i$ は地震発生時に おけるD.Index別潘目の棟人口、Pwは住宅形式（独立/集合）別棟人 口、Er 地地震発生時（曜日,時間）に扩ける当該地域の在宅率（図5） である。行政区を集計単位とし地域内建物棟数でサメーションし、木 造独立住宅と木造集合（長屋建十共同建）に関して算出したのが図6 である。損傷度と棟死亡率との関倸は極めて明快でありD.Indexが 0.6 を超える被害を被ると死者が発生し始め、以後、棟死亡率は急增する。 その勾配は急峻であり、住宅形式に無関保に一般に“全壊”之定義さ れている建物被害（D.Index：0.6〜1.0）において、建物が傾斜した程

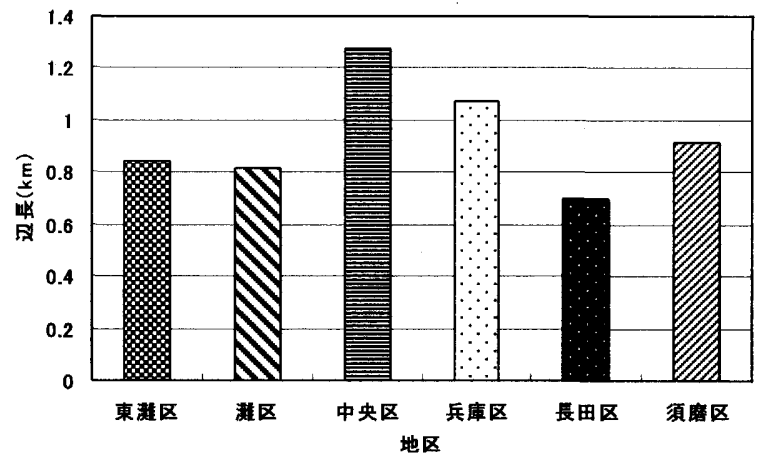

図8 建物被害判定地区を正方と仮定した際の辺長
度（D4 LEVEL、D.Index=0.6-0.8） と完全崩壊（D6 LEVEL、D.Index =0.9-1.0）とでは、棟死亡率は著しく異なり、木造独立住宅では最大 で10倍以上の差がある。人命損失を考える際には、既往の建物被害尺 度では十分な精度が保証されないことを強調しておく。加えて、木造 独立住宅に比べて、集合住宅の死亡危険度のばらつきが大きい傾向に あることが確認できる。

\section{（1）全壊率が棟死亡率に与える影響について}

建物の損傷度で棟死亡率をある程度説明することができたが、図6 において地域差を認めることができる。その理由を、地域の全壤率の 違いから考察する。図7に町丁目ごとの全壊率と、D-LEVEL別の棟数 当たりの死亡者数を示す。D4・D5・D6 LEVELはともに、相関係数R は高くはないものの、概ね周辺の全壊率が高くなると、建物が同一損 傷であっても死亡危険度が高くなる傾向が認められる。図3において 死者の多くが 6 時間以内に死亡している事寒を示した。それ以前に救 助を行わなければ死亡率が上がることを意味している。すなわち、地 震時に負傷した者は、倒壊した建物からの救助時間に反比例して、生 存率が下がる。全壊率の高い地域は、低い地域に比べ混乱状況が酷烈 であり、発災から救助時間が長くなり、同じ建物損傷下でも死亡率が 高くなることが容易に推測できる。

実はこの周辺全壊率の違いが、大規模被害地震と小規模被害地震に おける死者数発生割合の不一致を説明する一つの理由ではないかと 推測する次第である。既往式(1)〜(4)においては、建物被害数と死者 とは線形回帰が基本であり地域被害の大小は考慮に入っていないた め、大規模被害地震では死者数を過小評価し小規模被害地震では過大 評価となってしまう。死者数予測式に周辺全壊率を取り込んだもう一 つの理由として防災対策的観点がある。周辺全壊率はSAR(Search And Rescue)等のその後の死者低減応急対策の難易性など、対策に関わる ファクターでもある。相関性は高くないとはいえ、死者発生に関与す ることは疑いのないところであり、死者低減のための対策効果評価が 可能になるなど、式の有用性を高める意味において導入を企図した。

（2）全罗率を考慮する周辺範囲について

個別の建物損傷による死亡に影響を与える周辺の範囲（規模）につ いて検討しておく。集計する地域の規模により被害率や死亡率は大き く影響を受けるからである。本研究で建物被害調查を行った町丁目の 面積をGISポリゴンの町丁目面積から概算した上で、行政区で集約し 正方であると見做した時の辺長（km）で代表させる（図8）。多少、 地域により大小が認められるものの、全地域を平均すると $0.93 \mathrm{~km} 、 す$ 


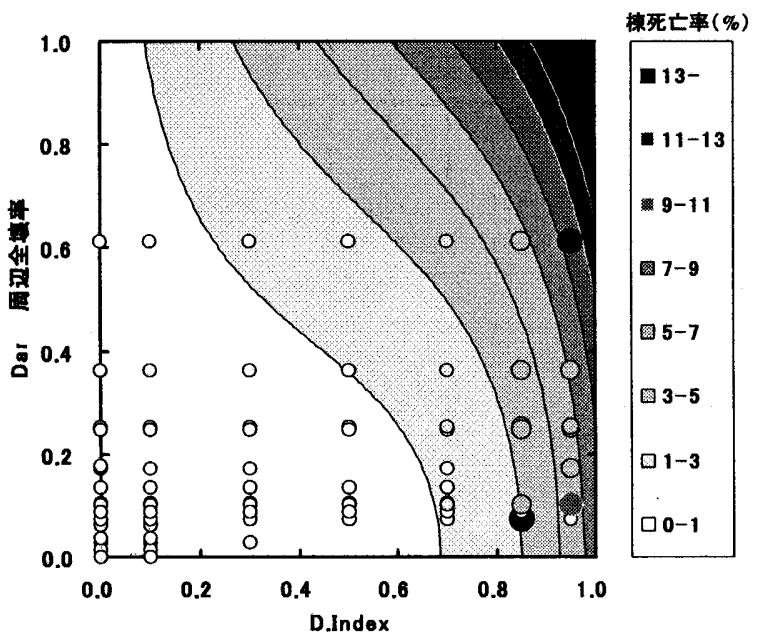

(1)木造独立 (一戸建)

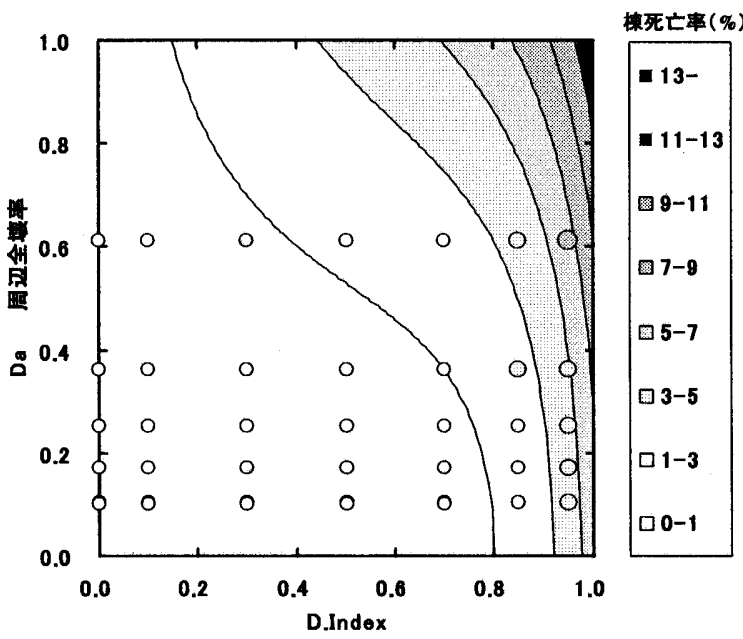

(2)木造集合 (長屋建·共同建)

図9 棟死亡率関数2次元表示と地域ごとの棟死亡率(\%)

なわち、概ね $1 \mathrm{~km}$ 四方であると見做すことができる。この大きさは、 国土数値情報3次メッシュ統計 ${ }^{20}$ に一一致し、利用の便が高いので、以 後この値を用いることを提案する。

\section{4. 木造低層建物棟死亡率閶数の作成}

\section{1 木造低層建物棟死亡率阙数}

本研究の目的である建物 1 棟ごとの死亡率推定式（棟死亡率関数） を次に求める。前節の考察より棟死亡率はその建物の損傷度 (D. Index 表記）及び周辺地域（約 $1 \mathrm{~km}$ 四方）の全壊率に影響されると考えられ るので、2 変数で関数を構成する。図6及び図7より、両変数と棟死亡 率との関係をそれぞれ指数関数及び二次関数で単純化し、かつ周辺地 域の全壊率が高くても当該建物損傷が半壊以下の場合は死亡者の発 生はみないことを考虑し、以下の関数型（式(9)）を仮定する。デー 夕に最尤法的に関数を回帰しそれぞれの係数を求める。用いたデー夕 は、本来全建物 13,129 棟に対して \{建物損傷度、周辺全壊率、棟死亡 率\} のデータセットを作成し回帰すべきであるが、計算効率を上げる ため周辺全壊率 (D. Indexが0.6 1.0で全壊と判定されたものの割合を 定義域[0,1.0]で計算）を区単位で集計し、区ごとに各D-LEVEL（D0 〜D6）に相当する建物の死亡率平均を求め回帰用の 2 次デー夕を作 成し回帰した。6区×7D.Index（各D-LEVELの中央值で代表）=42（棟 平均死亡率）データの内、極端に建物数が少ないものを除いて式(9) を回帰した。木造独立住宅に関しては、2004年新潟県中越地震におけ る被害 ${ }^{21)}$ を追加することで、より全壊率が低い場合にも配慮した。

$$
\operatorname{Dr}(x, y)=a e^{b x}+c x y^{2}
$$

ここに、 $\operatorname{Dr}(x, y)$ は棟死亡率（\%）を表す。定義域は 0 ～100\%である。 $x$ は損傷度（D.Index、定義域 $[0,1]$; 但し、0.6未満の半壊以下では死者 は発生しないものとしカウントしない)、yは周边全壊率(定義域 $[0,1]$ )、 $a, b, c$ は木造住宅形式（独立/集合）別の係数であり、表4のとおりに 求められた。係数 c が周辺全罣率の影響を表す值であり、木造独立で 発生する死者の方が周辺全壊率の影響を大きく受けるのが分かる。図 9に、回帰に用いた 2 次デー夕（濃淡および○の大きさで棟死亡率を 表記）と回帰した関数（濃淡で死亡率を表記）を 2 次元平面上に図示 する。重相関俰数は独立住宅（図9(1)）が0.818、集合住宅（図9(2)）
が0.945で、良く適合していると言えよう。図10が、得られた木造独 立住宅の棟死亡率関数であり、Z-軸に目的変数の棟死亡率（Death Ratio (\%)）を、X-及びY-軸に説明変数の建物損傷度（D. Index）と周 辺全壊率（Damage Ratio）をとり、3 次元で示す。周辺全壇率の影響 は建物損傷度が大きいほど大きくなる。たとえば、周辺全墙率が高く ても当該建物の損稘度が小さければ死亡率は低いものの、建物損傷度 が0.6程度であれば周辺全壊率が0.6（60\%） を超えると、棟死亡率の 増加傾向が急になるのが読み取れ、死亡被災現象の表現として受容で きるであろう。

\section{2 棟死亡率閣数の検証}

棟死亡率関数の評価精度を検証するために兵庫県南部地震の町丁 目単位における死者数を推定する。その際、当該地震における実際の 建物被害を既知数として与え、代表的な既存式との推定精度比較を行 う。既存式として、河角式(1)と東京都の式(2)を採用した。図11が推 定結果である。提案式による推定値は、比較のために、全滾率を考虑 しない場合と併記した（同図(a)(b)(c)）。明らかに、全壊率を考虑し た効果が認められる。本提案式の推定精度の高さに比較し、河角式 .

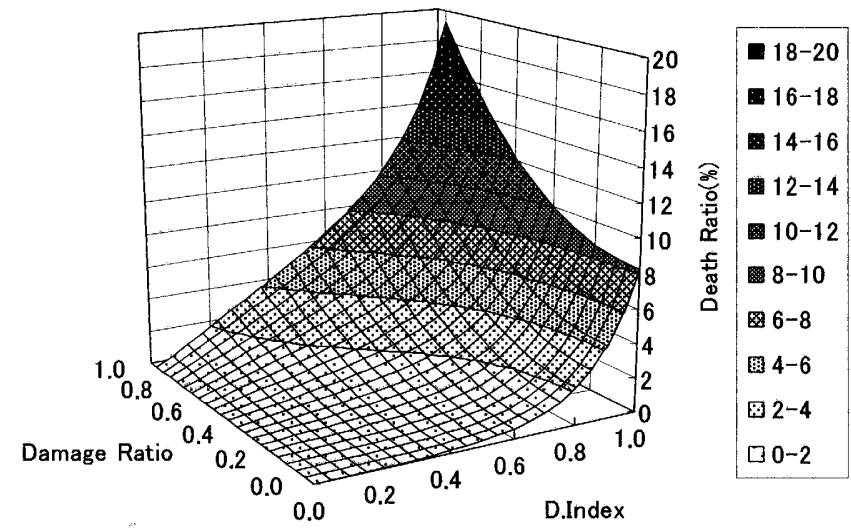

図10 木造低層建物棟死亡率関数3次元表示(木造独立)

表4 木造低層建物棟死亡率関数パラメータ

\begin{tabular}{c|c|c}
\hline 住宅形式 & 木造独立 & 木造集合(長屋·共同建) \\
\hline$a$ & 0.0104 & 0.000580 \\
\hline$b$ & 6.68 & 9.32 \\
\hline$c$ & 11.0 & 6.69 \\
\hline 重相関係数 & 0.818 & 0.945 \\
\hline
\end{tabular}




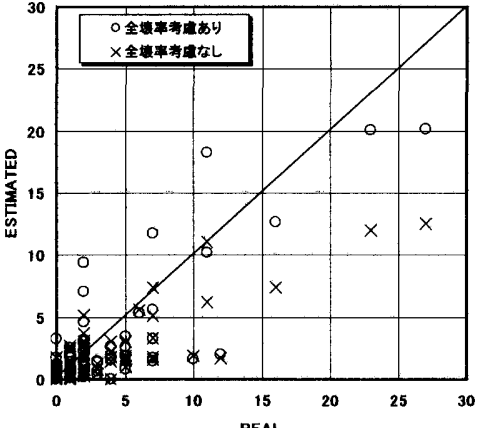

(a)提案式(木造独立)

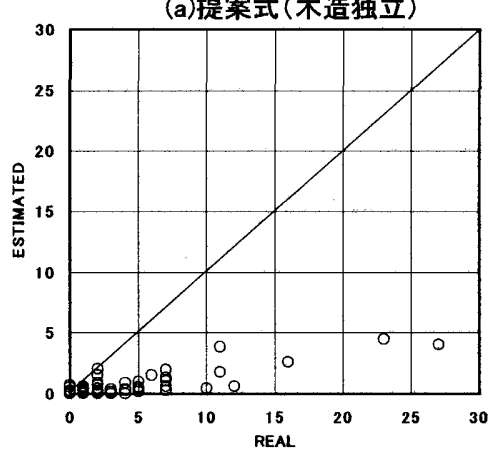

(d)河角式 (木造独立)

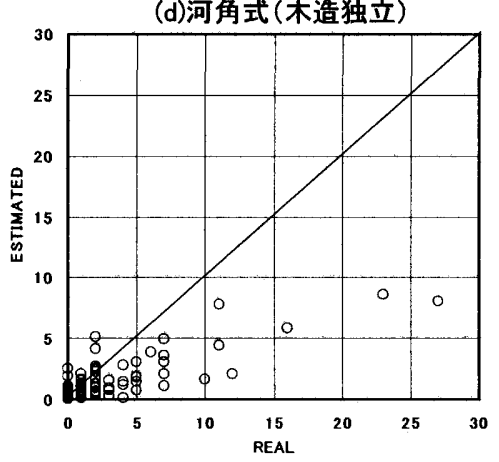

（g)東京都被害想定式（木造独立）

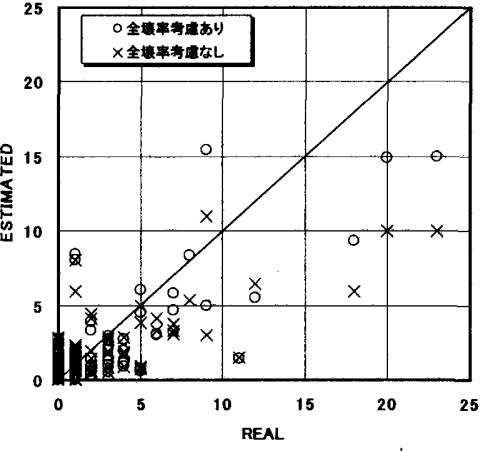

(b)提案式(木造集合)

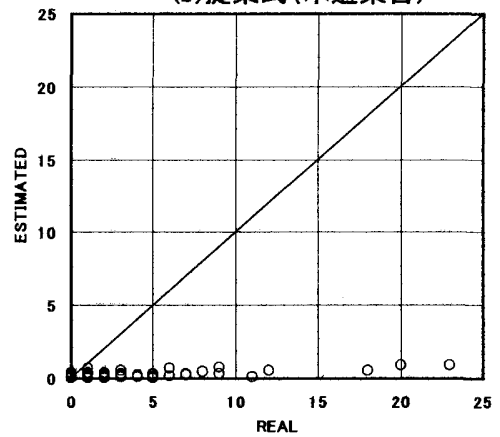

(e)河角式(木造集合)

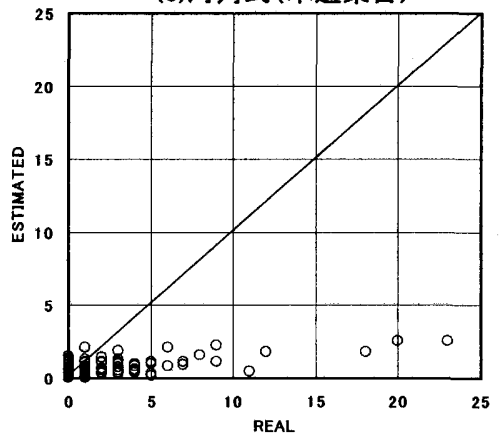

(h)東京都被害想定式(木造集合)

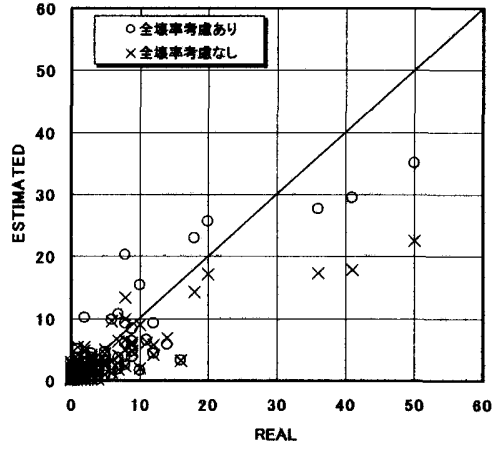

(c)提案式 (木造計)

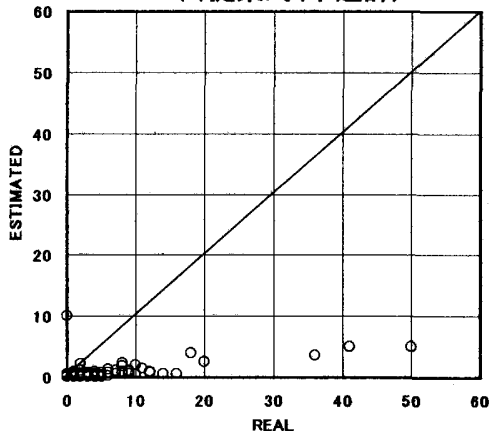

(f)河角式 (木造計)

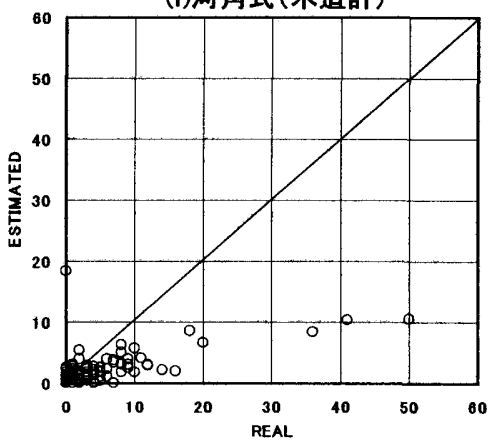

(i)東京都被害想定式(木造計)

図11 実際の木造低層建物被害から推定した死者数と実数との比較

東京都式共に大幅な過小評価となっている。特に河角式にその傾向が 強い。兵庫県南部地震では東灘区のように住家の完全崩壊（D5ある いはD6 LEVELの損傷）が多くかつ周辺地域の全壊率が高く多くの死 者を発生した区がある。D4を含め全壊を一括りで扱う従来式では、 東灘区の被害状況を評価できず過小評価となってしまう。建物被害尺 度をD. Indexで詳細に扱う必要性が確認できる。

\section{5. 広域震害予測へ向けた木造低層建物棟死亡率関数の汎用性の検討}

作成した棟死亡率関数の他地震への適用可能性について検討する。 手順は以下のとおりとなる。

(1)既往地震にお㧍ける実際の建物被害を入手

(2)周辺地域の全壊率を(1)より求める。

(3)本提案の棟死亡率関数（式(9)）に(1)と(2)を代入し、棟死亡率を 得る。

(4)当該建物の居住者人口または当該地域の平均居住者人口に、該当 時間の滞在率（NHK国民生活時間調查結果）を乗じ在宅人口を 得(3)に乗じることで死亡者数を得る。

兵庫県南部地震発生後、幸いなことに大規模被害地震は発生しておら
ず、建物倒壊に伴う死者発生は2004年新潟県中越地震のみであるので、 この地震について死者数の評価比較を河角式(1)および東京都の式(2) で行う。地震発生は、2004年10月23日（土）17時56分、最大震度は7 （K-NET小千谷,JMA川口）である。図12にK-NET加速度記録から算 定した計測震度をスムージングして市町村単位に割り付けた震度分 布を示す。小千谷市を中心として震度6弱から6強の分布が見られる。 消防庁発表による被害集計（第69報）によれば、新潟県全体における 人的被害は、死者 51 名・重傷者 635 名・軽傷4,160名であるが、死者の うち建物の倒壊が直接的原因となったものは10名である。表5に建築

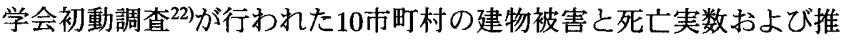
定死者数の関係を示す。先の図11とは逆に、既存式が大幅な過大評価 となっている。提案式は若干過大評価ではあるが既存式よりも精度良 く推定できている。長岡市や堀之内町において、比較的全壊数が多い にも関わらず死者が発生していないのは、地震発生時に住人がいない 建物が被災したか、或いは救助・医療機関への搬送が迅速に行われた 等の可能性が考えられる。今後のデー夕拡充を待って推定精度のさら なる改善を試みる予定である。 
表5 建築学会初動調査 ${ }^{211}$ にる2004年新潟県中越地震の市町村別被害と推定死亡者数

\begin{tabular}{|c|c|c|c|c|c|c|c|c|c|c|c|c|c|}
\hline \multirow[b]{3}{*}{ 市町村 } & \multicolumn{8}{|c|}{ 木造建物被害 } & \multirow{3}{*}{ 全壊率 } & \multirow{3}{*}{$\begin{array}{l}\text { 死亡 } \\
\text { 实数 }\end{array}$} & \multirow{2}{*}{\multicolumn{3}{|c|}{ 推定死亡者数 }} \\
\hline & \multicolumn{7}{|c|}{ D-LEVEL } & \multirow{2}{*}{ 総尌 } & & & & & \\
\hline & DO & D1 & $\mathrm{D} 2$ & D3 & DA & D5 & Do & & & & (1)式 & (2)式 & 提案式 \\
\hline 小国町 & 36 & 31 & 1 & 3 & ex: & (3) & rill? & 72 & 0.014 & 0 & 0.01 & 0.15 & 0.02 \\
\hline 小千谷市 & 1109 & 639 & 222 & 103 & 130 & 17 & 13 & 2233 & 0.072 & 5 & 7.33 & 13.7 & 5.25 \\
\hline 柏崎市 & 13 & 1 & & & 3 & Try & & 17 & 0.176 & 0 & 0.04 & 0.27 & 0.08 \\
\hline J11口町 & 161 & 199 & 48 & 63 & 113 & 28 & $(8)$ & 625 & 0.246 & 4 & 6.98 & 12.7 & 6.84 \\
\hline 川西町 & 82 & 32 & 6 & 9 & 3 & 2 & 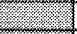 & 134 & 0.037 & 0 & 0.08 & 0.59 & 0.18 \\
\hline 越路町 & 19 & 59 & 12 & 9 & 3 & & (1) & 102 & 0.029 & 0 & 0.04 & 0.42 & 0.06 \\
\hline 十日町市 & 58 & 43 & 9 & 9 & 8 & the & 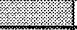 & 127 & 0.063 & 1 & 0.15 & 0.84 & 0.17 \\
\hline 杤尾市 & 24 & 19 & & & 8 & 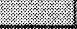 & 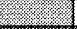 & 43 & 0.000 & 0 & 0.00 & 0.00 & 0.00 \\
\hline 長岡市 & 343 & 444 & 132 & 64 & 83 & 111 & . & 1077 & 0.087 & 0 & 3.67 & 8.28 & 2.47 \\
\hline 堀之内町 & 176 & 103 & 25 & 26 & 48 & 1 & 2 & 381 & 0.134 & 0 & 1.66 & 4.47 & 1.42 \\
\hline 総該 & 2021 & 1570 & 455 & 286 & 392 & 59 & 28 & 4811 & & 10 & 20.0 & 41.4 & 16.5 \\
\hline
\end{tabular}

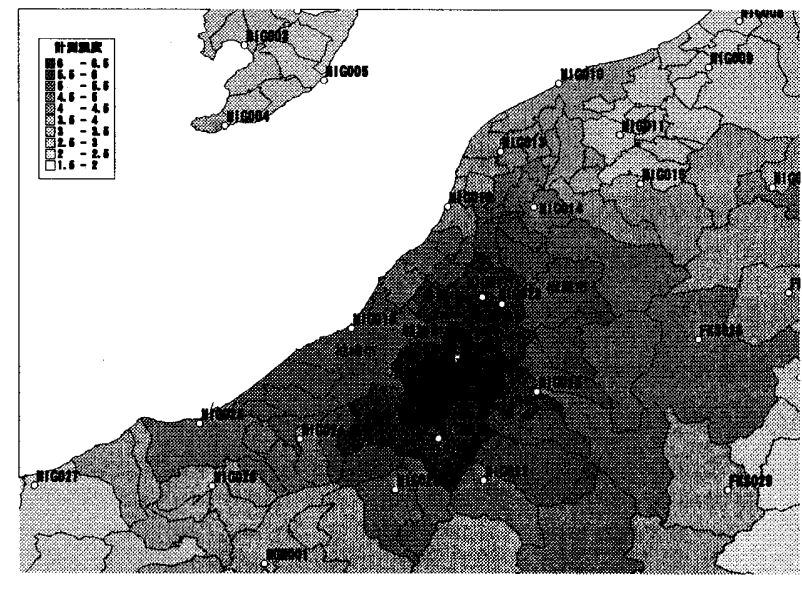

図12 2004年新潟県中越地震の計測震度分布(K-NETより算定)

6. おわりに

本研究では、兵庫県南部地震の木造低層建物被害を航空写真から調

查し、建物個別の損傷度と周辺全壊率、死亡率との関係を明らかにし、 木造建物の 1 棟当たりの死亡率関数（棟死亡率関数）を構成した。以 下に成果をまとめる。

（1）木造建物内における死者発生が、建物個別の損傷度および周辺 の全壊率と深い関倸にあることを示した。損傷度および全壊率が 高くなることで、建物内から救助される時間をより要し、死亡率 が高まるためと推察される。

（2）建物損傷尺度を細分化することで死者数推定精度が改善された。

（3）地震発生時の在宅率（NHK国民生活時間調査結果）を明示的

に用いることにより、死亡率評価精度が向上した。

(4) 周辺全壊率を考慮することにより兵庫県南部地震のような甚大 被害のみならず、人的被害が比較的軽微な地震についても既往式 より高い精度で推定可能である。

本提案の棟死亡率関数は、既往地震のみならず将来的に想定された 地震に対しても地域の耐震診断值データ 22 、建物損傷度関数9)や地震 調查研究推進本部地震調査委員会 (推本) 並びに自治体が独自に公開 している地震ハザードマップ等を併用し、地震動を既知情報として死 者推定に用いることができる。既往式に比べ推定精度の向上が見込ま れるのみならす、住民に対して個々のケースごとに耐震補強効果を死 亡危険度を指標として提供することも可能になるなど個人の防災意 識啓発を含め防災的応用例は広い。具体的な利用法は別報で報告する 予定である。

本研究を進めるにあたり、建物・行政区界等GISデジタル記録、人 的被害記録、推定地震動等に関する統計デー夕を使用させて頂きまし
た。人的被害に関しては、横浜市立大学の西村明儒氏、京都大学の林 康裕氏には、兵庫県南部地震の推定最大地動速度を提供して頂きまし た。防災科学技術研究所には、K-NETの強震記録を利用させて頂きま した。また、本論文の作成にあたっては、米テキサス大学の青木則明 氏には、法医学的見地から貴重なご助言賜りました。また、航空写真 の読み取りには北海道大学の名知典之・三輪田吾郎両氏の協力を得、 同高井伸雄氏には有益な意見を多く頂戴しました。記して梁く御礼申 し上げます。

注）筆者らによる被害率関数も全壊をD4とD5以上の 2 分類するに留まってい る。さらに高分解な関数を別稿で準備中である。

\section{参考文献}

1）建設省住宅局監修：増強版 木造住宅の耐震精密診断と補強方法，(財）日 本建築防災協会, 1-94,1995.

2) Kawasumi $\mathrm{H}$ : Intensity and Magnitude of shallow Earthquakes,Bereau Central Seism. Intern. Ser. A, Trav, Sci.,19,99-114,1954.

3) 東京都防災会議,1978.

4）太田裕・後藤典俊 - 大檑ひとみ：地震時の死者発生数予測に関する実馱式 の一構成, 地震2, 36, 463-466,1983.

5) A.W.Coburn, R.J.S.Spence \& A.Pomonis : Factors determining human casualty levels in earthquakes:Motality prediction in building collapse, 10th World Conference on Earthquake Engineering,10,5989-5994,1992.

6) 内閣府防災担当ホームページ http://www.bousai.go.jp/manual/manual.html

7）福島誠志・河田恵昭・西村明儒・林春男・田中聡：EDAを用いた人的被害 の推定法の開発,地域安全学会,52-55,1997.

8）静岡県防災資料,東海地震第3次地震被害想定結果 http://www.e-quakes.pref.shizuoka.jp/data/pref/higai/houkoku/index.html

9）网田成幸・高井伸雄 : 木造建筑物の損傷度関数の提案と地震防災への適用 一地震動入力を確定的に扱亏場合一,日本建築学会構造系論文集, $582,31-38$, 2004.

10）小川直榯・山崎文雄 : 航空写真を用いた兵庫県南部地震における建物被害 の目視判読,地域安全学会論文集,2,119-128,2000.

11）建設省建筑研究所: 平成7年兵庫県南部地震被害調査最終報告青 第 $I$ 編 中間報告書以降の調查分析結果,1-303,1996.

12）岡田成幸・高井伸雄 : 地震被害調查のための建物分類と破壊パ夕ーン,日本 建築学会構造系論文集,524,65-72,1999.

13）生田英輔・宮野道雄・系魚川栄一・西村明儒・田中裕・暒原浩一・熊谷良 雄 : 統合データベースに基づく兵庫県南部地震による人的被害の発生機構 に関する分析,日本建築学会計画系論文集,590,117-123,2005.

14）林康裕・宮腰涼一・田村和夫・川瀬搏：1995年兵庫県南部地震の低層建物 被害率に基づく最大地動速度の推定,日本建策学会構造系論文集,494,59-66, 1997.

15）林康裕・宮腰淳一・田村和夫：1995年兵庫県南部地震の建物被害に基づく 最大地動速度分布に関する考察,日本建築学会構造系論文集,502,61-68, 1997.

16）長谷川浩一・翠川三郎・松岡昌志 : 地域メッシュ統計を利用した広域での 木造建築物群の震害予測 一その 2 建築年代別木造建築物の被害関数 の作成と震害予測例一,日本建築学会構造系論文集,505,53-59,1998.

17) 総務省統計局: 平成5年住宅統計調查報告,第3巻,都道府県編

18）総務省統計局: 平成 5 年住宅統計調查報告,第 1 巻,全国編

19) NHK放送文化研究所 : データブック国民生活時間調查2000（県別）,2001.

20) 国土交通省国土計画局ホームページ http://www.mlit.go.jp/kokudokeikaku/kokudokeikaku.html（2005年10月現在）

21）日本建策学会：2004年新潟県中越地震炎害調查報告,2006（印刷中）

22）高井伸雄・岡田成幸 : 木造損賃度関数作成のための精密耐震衫断值の地域 特性及び年代特性の把握,日本建築学会北海道支部研究報告集, 76,37-40, 2003.

（2005年10月 10 日原稿受理，2006年 3 月 23 日採用決定） 